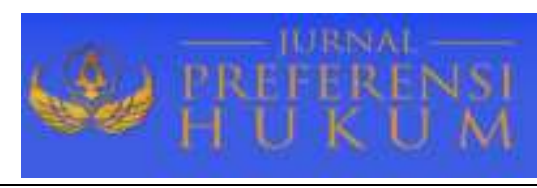

Jurnal Preferensi Hukum | ISSN: XXXX | E-ISSN: XXXX

Vol. 1, No. 2 - September 2020, Hal. 139-144| Available Online

at https://www.ejournal.warmadewa.ac.id/index.php/juprehum

DOI: http://doi.org/ 10.22225/jph.v1i2.2351.139-144

\title{
TINJAUAN YURIDIS TERHADAP TINDAK PIDANA PUNGUTAN LIAR (PUNGLI)
}

\author{
I Wayan Arsa Yogi Wiguna, I Nyoman Sujana, I Nyoman Gde Sugiartha \\ Fakultas Hukum Universitas Warmadewa, Denpasar-Bali, Indonesia
}

\begin{abstract}
Abstrak
Di masyarakat sering terdengar tentang pungutan liar yang merupakan salah satu bentuk tindak pidana. Penelitian ini bertujuan untuk mengetahui pengaturan terhadap tindak pidana pungutan liar (Pungli) berdasarkan Peraturan Daerah Nomor 8 Tahun 2010 tentang tentang pungutan retribusi, kreasi dan olahraga dan untuk mengetahui pengenaan sanksi pidana terhadap pelaku yang melakukan tindak pidana pungutan liar (Pungli). Metode penelitian yang digunakan yakni metode penelitian normatif, sumber bahan hukum primer dan sekunder, pencatatan terhadap buku-buku peraturan perundang-undangan serta literatur lainnya dilakukan untuk mengumpulkan data, dan analisis bahan hukum dengan menggunakan argumentasi hukum. Hasil dari penelitian ini bahwa terkait dengan pengaturannya tersirat dalam rumusan korupsi pada beberapa Pasal diantaranya Pasal 423 KUHP yang dirujuk dalam pasal 12 Undang-Undang Nomor 31 Tahun 1999 sebagai tindak pidana korupsi, yang kemudian dirumuskan ulang pada Undang-Undang Nomor. 20 Tahun 2001 tentang tindak pidana korupsi. Sanksi hukum terhadap pungutan liar terdiri atas sanksi sosial, sanksi pidana. Perundangan tnetnag tindak pidana korupsi tercantum di dalamnya tentang tindak pidana pungutan liar.
\end{abstract}

Kata Kunci: Pengaturan; Pungutan liar; Sanksi

\begin{abstract}
In the community, it is often heard about illegal fees which are a form of criminal act. This study aims to determine the regulation of illegal levies (Pungli) based on Regional Regulation No. 8/2010 concerning levies, creations and sports and to determine the imposition of criminal sanctions against perpetrators who commit illegal extortion (Pungli). The research method used is the normative research method, primary and secondary legal material sources, records of statutory books and other literature are carried out to collect data, and analysis of legal materials using legal arguments. The results of this study indicate that the regulation of corruption is implied in the formulation of corruption in several articles including Article 423 of the Criminal Code referred to in Article 12 of Law Number 31 Year 1999 as a criminal act of corruption, which is then reformulated in Law Number. 20 of 2001 concerning the crime of corruption. Legal sanctions against extortion consist of social sanctions and criminal sanctions. The law on corruption is stated in it regarding the crime of extortion.
\end{abstract}

Keywords: Regulations; Illegal Levies; Sanctions

\section{PENDAHULUAN}

Pungutan liar dan korupsi pada intinya adalah tindakan yang sama karena sama-sama mempergunakan kekuasaan untuk membuat kaya diri yang bertentangan dengan hukum. Tindak pidana ini tersirat pada perundangan tentang korupsi. Pungutan liar dengan kata lain juga disebut dengan pungutan yang dilakukan demi kepentingan pribadi dikarenakan petugas yang tidak memiliki moral atau melakukan pelanggaran aturan. Adanya wewenang yang disalah gunakan dengan tujuan memfasilitasi masalah atau memenuhi kepentingan pihak yang membayar. Jadi dapat dikatakan pungli setidaknya ada dua pihak, baik pihak yang menggunakan jasa atau petugas yang tidak bermoral yang sudah terbiasa melakukan hubungan langsung untuk melakukan transaksi tertutup dan terbuka, pungli biasnaya terjadi di di lapangan dilakukan dengan cepat dan dan berbentuk uang.

Pemerintah telah mengeluarkan Peraturan Presiden tentang Satuan Tuntas Sapu Bersih Pungutan Liar yang mendapatkan dukungan Surat Edaran Menteri Pendayagunaan Aparatur Negara Reformasi Birokrasi dalam melaksanakan tupoksi pemerintahan. Tujuan dibentuknya perundangan adalah agar kepentingan individu dan masyarakat terlindungi (Lamintang, 1991) Pungli yang 
dilakukan oleh oknum pejabat ketika memberikan pelayanan kepada masyarakat agar bisa diminimalisasi dengan terbitnya peraturan presiden ini. Praktik pungli adalah perbuatan merusak, busuk dan bejat serta banyak kebohongan yang dikaitkan dengan masalah uang, berhasilnya pemberantasan pungli dalam hal ini korupsi akan memberikan dampak yang baik bagi masyarakat (Ramadhani, 2017).

Dalam penanaganan masalah pungli setiap daerah provinsi termasuk kabupaten/kota juga telah mengeluarkan Perda. Hal ini dilakukan agar lebih jelasnya pijakan hukum mengenai kasus Pungli ini. Sebagai salah satu daerah pariwisata yang ada di Provinsi Bali, Pemerintah Kabupaten Gianyar memiliki Perda yang mengatur tentang retribusi tempat rekreasi yaitu Perda Nomor 8 Tahun 2010 yang mengatur tentang retribusi tempat rekreasi dan olahraga. Perda tersebut dikeluarkan oleh pemerintah agar adanya kejelasan aturan mengenai bentuk retribusi dari tempat rekreasi dan untuk menghindari adanya pungutan-pungutan liar dari pihak-pihak tertentu. Meskipun telah terdapat aturan namun praktek pungli masih kerap ditemukan di masyarakat.

Salah satu kasus mengenai pungli yang sedang hangat dibicarakan yang terjadi di Kabupaten Gianyar adalah kasus pungutan karcis masuk Pura Tirta Empul yang dianggap tidak sesuai dengan Perda dan perjanjian. Dilansir dari Bali post (13 November 2018) Tim Sapu Bersih Pungutan Liar (Saber Pungli) Polres Gianyar melakukan penangkapan terhadap dua penjaga tiket di tempat wisata Tirta Empul, Desa Manukaya Let, Gianyar. Dari hasil pemeriksaan, penyidik menemukan dugaan tindak pidana korupsi dalam pungutan tiket. Pungutan ini diindikasikan melanggar Perda Kabupaten Gianyar Nomor 8 tahun 2010 tentang pungutan retribusi, kreasi dan olah raga dan turunannya yakni Perda retribusi objek wisata.

Dari Perda tersebut lebih lanjut kemudian dibuatkan kerja sama antar Dinas Pariwisata dengan Bendesa Adat Manukaya Let yang kemudian disebut Perarem Desa Manukaya Let no 4 tahun 2013 terkait pemungutan tiket wisata. Perjanjiannya sendiri sudah dilakukan dua kali, yakni pada awal tahun 2013 dan bulan April 2018 dalam perjanjian ini disebutkan adanya pembagian hasil tiket mulai dari pukul 07.00 Wita hingga 18.00 Wita. Yakni Pemerintah Daerah (Pemda) mendapat bagian 60 persen dan Desa Manukaya Let sebesar 40 persen. Namun sejak tahun 2013, secara sepihak ada yang memerintahkan karyawan dari Bendesa Adat untuk mengambil alih tiket pada pukul 15.00 Wita hingga 18.00 Wita. Hal ini jadi permasalahan karena uang hasil penjualan tiket tidak dibagi sesuai Perda Nomor 8 tahun 2010. Uang itu seluruhnya masuk ke uang kas Desa Adat. Selain itu, selama lima tahun terakhir, Desa Adat juga telah menerima hak 40 persen dari penjualan tiket pukul 07.00-15.00 Wita. Namun dari pukul 15.00-18.00 Wita diambil seluruhnya oleh Desa yang membuat Pemda merasa dirugikan.

Meskipun dikatakan dalam perjanjian tidak tercantum batas waktu operasional namun dengan jelas, dalam kasus ini Perarem Desa Manukaya Let no 4 tahun 2013 dan telah diperpanjang pada april 2018 terkait pemungutan tiket wisata tidak bisa berlaku, karena berbenturan dengan aturan yang ada diatasnya, yakni Perda Kabupaten Gianyar no 8 tahun 2010 tentang pungutan retribusi, kreasi dan olah raga. Kompleksnya permasalahan pungling, karena menyangkut hak-hak masyarakat yang harus dilindungi. Pelaksanaan pelayananan publik menjadi terhambat karena adanya pungli. Kewibawaan hukum menjadi merosot dengan maraknya pungli (Soepardi, 2009). Upaya yang dilakukan untuk memberantas pungli adalah dengan melakukan penegakan hukum sehingga kepastian dan ketertiban serta perlindungan hukum dapat terjamin dan dilaksanakan di era modernisasi dan globalisasi ini, jika berbagai dimensi kehidupan hukum selalu menjaga harmoni, keseimbangan dan harmoni antara moralitas sipil berdasarkan nilai-nilai aktual dalam kehidupan masyarakat yang beradab (Hamzah, 2000).

Berdasarkan pernyataan sebagaimana diuraikan diatas, penelitian ini hendak mendeskripsikan pembahasan dalam fokus masalah hukum terhadap terhadap praktek pungli yang terjadi di masyarakat. Oleh karena alasan-alasan tersebut di atas, praktek pungli cukup sulit untuk dihilangkan mengingat bahwa hukum di Indonesia yang mengatur masalah ini terdapat konflik norma tentang pengaturan Pararem dengan Perda tentang retribusi yang dimanfaatkan oleh pelaku pungli untuk lepas dari proses pemidanaan. Maka penelitian ini betujuan untuk mengetahui pengaturan terhadap tindak pidana pungutan liar (Pungli) berdasarkan Peraturan Daerah Nomor 8 Tahun 2010 tentang tentang pungutan retribusi, kreasi dan olahraga, dan juga untuk mengetahui pengenaan sanksi pidana 
terhadap pelaku yang melakukan tindak pidana punguta liar (Pungli) pada kasus karcis masuk Pura Tirta Empul.

\section{METODE PENELITIAN}

Metode penelitian yang digunakan dalam penelitian ini yaitu jenis penelitian yuridis normative, dengan menggunakan pendekatan peraturan perundang-undangan, pendekatan konseptual dan pendekatan kasus dengan menganalisis kasus (Sudarto, 1986). Bahan hukum yang digunakan dalam penelitian ini terdiri dari 2 macam sumber, yaitu bahan hukum primer yaitu Undang-Undang dan peraturan lainnya serta bahan hukum sekunder. Sumber data yang digunakan dalam pengumpulan data yaitu bahan hukum primer dan sekunder; sumber data ini merupakan metode pengumpalan bahan hukum dengan melakukan pencatatan terhadap buku-buku peraturan perundangan-undangan serta literatur lainnya yang ada kaitannya dengan masalah yang di bahas. Bahan ini yang telah terkumpul dianailisis secara sistematis dengan menggunakan argumentasi hukum berdasarkan logika hukum deduktif, induktif dan dituangkan secara deskriftif.

\section{HASIL DAN PEMBAHASAN}

\section{Pengaturan terhadap Tindak Pidana Pungutan Liar (Pungli)}

Secara mendasar, penegakan hukum adalah menegakkan ide-ide atau konsep-konsep yang abstrak, dalam rangka mengubah ide-ide tersebut menjadi nyata (Rahardjo, 2010). Menurut Philipus M. Hadjon, adalah alat dalam melakukan penegakan hukum meliputi penegakan sanksi dan pengawasan (H.R., 2011). Pengawasan merupakan langkah preventif untuk memaksakan kepatuhan, sedangkan pemberian sanksi merupakan langkah represif untuk memaksakan kepatuhan. Dalam memberikan pelayanan publik aparat pemerintah seyogianya memberikan pelayanan secara maksiamal dan memberikan kepuasan kepada masyarakat (Wahyudi, 1994). Dari berbagai uraian arti pungutan liar diatas, sehingga dapat di lihat bahwa unsur-unsur dari perbuatan pungutan liar terdiri dari unsur obyektif dan unsur subyektif antara lain, yaitu:

a. Unsur Obyektif Pada pungutan liar hal ini diatur dalam rumusan korupsi pada Pasal 12 huruf e UndangUndang Nomor 20 Tahun 2001 berasal dari Pasal 423 KUHP adalah:

1. Pegawai negeri atau penyelenggara negara atau seorang pejabat;

2. Menyalah gunakan kekuasaan;

3. Memaksa seseorang yaitu terdiri atas: a) Memberikan sesuatu, b) Membayar, c) Menerima, d) Mengerjakan sesuatu bagi dirinya sendiri;

b. Unsur Subyektif Pada pungutan liar dalam hai ini adalah:

1. Menguntungkan diri sendiri atau orang lain;

2. Menguntungkan secara melawan hukum.

Adanya prosedur pelayanan yang lama dan berbelit-belit menyebakan masyarakat merasa lelah pada saat harus berurusan dengan pelayanan publik yang korup. Masyarakat menjadi toleran dengan praktik pungutan liar dalam menyelenggarakan pelayanan publik. Politik hukum pidana merupakan bagian dari kebijakan penanggulangan kejahatan lewat pembuatan peraturan perundangundangan pidana. Penegakan hukum harus dilihat sebagai sistem peradilan pidana, karena merupakan proses yang mencakup berbagai pihak yang didalamnya terdapat masyarakat untuk kerangka mencapai tujuan (Arief, 2001). Berdasarkan ketentuan pidana tersebut di atas, kejahatan pungutan liar dapat dijerat dengan tindak pidana di bawah ini:

1. Tindak pidana penipuan

Penipuan dan pungutan liar adalah tindak pidana yang mengandung unsur-unsur yang sama dan adanya keterhubungan, seperti untuk mempeorleh keuntungan bagi diri sendiri atau orang lain secara melanggar hukum dengan berbohong supaya orang lain memberikan barang atau sesuatu kepadanya.

2. Tindak pidana pemerasan

Penipuan dan pungutan liar adalah tindak pidana yang mana terdapat unsur-unsur yang sama dan saling berhubungan, antara lain untuk menguntungkan diri sendiri atau orang lain secara melawan hukum dengan rangkaian kekerasan atau dengan ancaman agar orang lain menyerahkan barang atau sesuatu kepadanya.

3. Tindak pidana korupsi 
Tindak pidana korupsi yang sangat erat kaitannya dengan kajahatan jabatan ini, karena rumusan pada pasal 415 pasal penggelapan dalam KUHP diadopsi oleh UU No. 31 tahun 1999 yang kemudian diperbaiki oleh UU No. 20 tahun 2001, yang dimuat dalam pasal 8.

\section{Sanksi Pidana Terhadap Tindak Pidana Pungutan Liar (Pungli)}

Dalam melakukan penegakan hukum pidana, ada 3 (tiga) unsur yang harus selalu diperhatikan, yaitu; Kepastian hukum (Rechtssicherheit), Kemanfaatan (Zweckmassigkeit), dan Keadilan (Gerechtigkeit). Kepastian hukum merupakan suatu perlindungan dari tindakan sewenang-wenang dan bertujuan untuk ketertiban masyarakat. Kemanfaatan dalam penegakan hukum ditujukan kepada masyarakat, diharapkan hukum tidak menimbulkan keresahan dalam masyarakat. Keadilan dimaksudkan agar pelaksanaan penegakan hukum harus adil bagi semua orang. Ketiga unsur ini haruslah mendapat perhatian yang seimbang, tetapi dalam praktik tidak mudah untuk mengusahakan perhatian yang seimbang di antara ketiga unsur tersebut.

Dalam praktik penegakan hukum tindak pidana umum dan khusus, ternyata ada cukup banyak contoh kasus yang menunjukkan bahwa sanksi pidana belum dilaksanakan yang memenuhi nilai-nilai tujuan pidana baik untuk memberikan efek jera kepada pelaku atau untuk memberikan efek pencegahan umum kepada masyarakat umum. Yang nantinya, penerapan sanksi pidana tersebut juga tidak mencerminkan nilai kebenaran, keadilan, kepastian, dan kegunaan hukum yang merupakan tujuan hokum. Salah satu kasus mengenai pungli yang sedang hangat dibicarakan yang terjadi di Kabupaten Gianyar adalah kasus pungutan karcis masuk Pura Tirta Empul yang dianggap tidak sesuai dengan Perda dan perjanjian. Dilansir dari Bali post (13 November 2018) Tim Sapu Bersih Pungutan Liar (Saber Pungli) Polres Gianyar melakukan penangkapan terhadap dua penjaga tiket di tempat wisata Tirta Empul, Desa Manukaya Let, Gianyar. Dari hasil pemeriksaan, penyidik menemukan dugaan tindak pidana korupsi dalam pungutan tiket. Pungutan ini diindikasikan melanggar Perda Kabupaten Gianyar Nomor 8 tahun 2010 tentang pungutan retribusi, kreasi dan olah raga dan turunannya yakni Perda retribusi objek wisata.

Dari Perda tersebut lebih lanjut kemudian dibuatkan kerja sama antar Dinas Pariwisata dengan Bendesa Adat Manukaya Let yang kemudian disebut Perarem Desa Manukaya Let no 4 tahun 2013 terkait pemungutan tiket wisata. Perjanjiannya sendiri sudah dilakukan dua kali, yakni pada awal tahun 2013 dan bulan April 2018. dalam perjanjian ini disebutkan adanya pembagian hasil tiket mulai dari pukul 07.00 Wita hingga 18.00 Wita. Yakni Pemerintah Daerah (Pemda) mendapat bagian 60 persen dan Desa Manukaya Let sebesar 40 persen. Namun sejak tahun 2013, secara sepihak ada yang memerintahkan karyawan dari Bendesa Adat untuk mengambil alih tiket pada pukul 15.00 Wita hingga 18.00 Wita. Hal ini jadi permasalahan karena uang hasil penjualan tiket tidak dibagi sesuai Perda Nomor 8 tahun 2010. Uang itu seluruhnya masuk ke uang kas Desa Adat. Selain itu, selama lima tahun terakhir, Desa Adat juga telah menerima hak 40 persen dari penjualan tiket pukul 07.00-15.00 Wita. Namun dari pukul 15.00-18.00 Wita diambil seluruhnya oleh Desa yang membuat Pemda merasa dirugikan.

Meskipun dikatakan dalam perjanjian tidak tercantum batas waktu operasional namun dengan jelas, dalam kasus ini Perarem Desa Manukaya Let no 4 tahun 2013 dan telah diperpanjang pada april 2018 terkait pemungutan tiket wisata tidak bisa berlaku, karena berbenturan dengan aturan yang ada diatasnya, yakni Perda Kabupaten Gianyar no 8 tahun 2010 tentang pungutan retribusi, kreasi dan olahraga. Undang-Undang Nomor. 20 Tahun 2001 perubahan atas Undang-Undang Nomor. 31 Tahun 1999 tentang Pemberantasa Tindak Pidana Korupsi dijelaskan diantaranya dalam Pasal 5 Undang-Undang Nomor. 20 Tahun 2001 bahwa; barang siapa, memberi atau menjanjikan sesuatu kepada pegawai negeri atau penyelenggara negara dengan maksud supaya pegawai negeri atau penyelenggara negara tersebut berbuat atau tidak berbuat sesuatu dalam jabatannya, yang bertentangan dengan kewajibannya; atau memberi sesuatu kepada pegawai negeri atau penyelenggara negara karena atau berhubungan dengan sesuatu yang bertentangan dengan kewajiban, dilakukan atau tidak dilakukan dalam jabatannya. Bagi pegawai negeri atau penyelenggara negara yang menerima pemberian atau janji sebagaimana dimaksud dipidana dengan pidana yang sama (Dipidana dengan pidana penjara paling singkat 1 (satu) tahun dan paling lama 5 (lima) tahun dan atau pidana denda paling sedikit Rp. 50.000.000,00 (lima puluh juta rupiah) dan paling banyak Rp 250.000.000,00 (dua ratus lima puluh juta rupiah). Pasal 11: Dipidana dengan pidana penjara paling singkat 1 (satu) tahun 
dan paling lama 5 (lima) tahun dan atau pidana denda paling sedikit Rp. 50.000.000,00 (lima puluh juta rupiah) dan paling banyak Rp. 250.000.000,00 (dua ratus lima puluh juta rupiah) pegawai negeri atau penyelenggara negara yang menerima hadiah atau janji padahal diketahui atau patut diduga, bahwa hadiah atau janji tersebut diberikan karena kekuasaan atau kewenangan yang berhubungan dengan jabatannya, atau yang menurut pikiran orang yang memberikan hadiah atau janji tersebut ada hubungan dengan jabatannya. Pasal 12; Dipidana dengan pidana penjara seumur hidup atau pidana penjara paling singkat 4 (empat) tahun dan paling lama 20 (dua puluh) tahun dan pidana denda paling sedikit Rp 200.000.000,00 (dua ratus juta rupiah) dan paling banyak Rp 1.000.000.000,00 (satu miliar rupiah), pegawai negeri atau penyelenggara negara yang dengan maksud menguntungkan diri sendiri atau orang lain secara melawan hukum, atau dengan menyalahgunakan kekuasaannya memaksa seseorang memberikan sesuatu, membayar, atau menerima pembayaran dengan potongan, atau untuk mengerjakan sesuatu bagi dirinya sendiri.

Kemudian pungutan liar dapat disamakan dengan tindak pidana pemerasan. Pemerasan adalah suatu jenis tindak pidana umum di Indonesia. Tindak pidana ini di atur dalam Pasal 368 KUHP; barang siapa dengan maksud untuk menguntungkan diri sendiri atau orang lain secara melawan hukum, memaksa seseorang dengan kekerasan atau ancaman kekerasan untuk memberikan sesuatu barang, yang seluruhnya atau sebagian adalah kepunyaan atau sebagian adalah kepunyaan orang itu atau orang lain, atau supaya membuat utang atau menghapuskan piutang. Pemerasan bermakna meminta uang dan jenis lain dengan ancaman Dalam konteks hukum pidana, unsur-unsur tindak pidana pemerasan dari Pasal 368 KUHP adalah 1) dengan maksud untuk menguntungkan diri sendiri atau orang lain, 2) secara melawan hukum, 3) memaksa seseorang dengan kekerasan dan ancaman, 4) memberikan atau menerima sesuatu barang, yang seluruhnya atau sebagian barang, yang seluruhnya atau sebagian adalah kepunyaan orang itu atau orang lain, dengan maksud membuat utang atau menghapuskan piutang.

Berdasarkan Surat Edaran Kejaksaan Agung Republik Indonesia Nomor B2479 / F.3 / Ft.111 / 2017 menjelaskan karena barang bukti kecil yang disita termasuk dalam kasus pemerasan kasus pidana umum sehingga dipindahkan ke pengadilan distrik untuk diadili, tetapi oleh pengadilan distrik dan diminta untuk diadili dalam tindak pidana korupsi karena pemerasan telah dimasukkan dalam kasus tindak pidana korupsi. Penyelesaian perkara tindak pidana pungutan liar yang disatukan dengan penyelesaian pidana korupsi sesuai dengan daerah hukumnya dilaksanakan oleh Kejaksaan Negeri Madiun sebagai lembaga yang berwenang didalam bidang penuntutan perkara tindak pidana korupsi.

\section{SIMPULAN DAN SARAN}

\section{Simpulan}

Berdasarkan penjelasan yang telah diuraikan diatas, maka dapat disimpulkan bahwa terkait dengan pengaturan tentang tindak pidana pungutan liar secara tersirat dapat ditemukan dalam rumusan korupsi pada beberapa Pasal diantaranya Pasal 423 KUHP yang dirujuk dalam pasal 12 UndangUndang Nomor. 31 Tahun 1999 sebagai tindak pidana korupsi, yang kemudian dirumuskan ulang pada Undang-Undang Nomor. 20 Tahun 2001 tentang tindak pidana korupsi. Kemudian, sanksi hukum terhadap pungutan liar terdiri atas sanksi sosial, sanksi pidana.

\section{Saran}

Saran-saran yang dapat diajukan berdasarkan hasil analisis adalah sebagai berikut; Agar pelayanan terhadap pelayanan pungutan liar dipertahankan dan ditingkatkan, agar tercapai komunikasi yang baik antara para pihak berwajib yang melakukan pelayanan terhadap pemberantasan pungutan liar ini. Kondisi yang seperti ini akan membantu mewujudkan keberhasilan di dalam perbaikan sistem birokrasi yang lebih baik kedepannya. Sehingga pelayanan publik kepada masyarakat akan terbesas dari segala kegiatan pungutan liar yang tidak sesuai dengan peraturan perundang-undangan. Selain itu bagi pihak yang melakukan pemberantasan pungli perlu meningkatkan kerjasama yang baik dengan Pemerintah dan maupun pihak Swasta dalam hal mempermudah pemberantasan kejahatan pungli. Kemudian, diperlukan adanya upaya sosialisasi oleh Pemerintah terkait dengan pentingnya tertib hukum dalam upaya mengindari terjadinya pungutan liar untuk menunjang peningkatan kesejahteraan 
masyarakat. Dalam hal ini menumbuhkan kesadaran masyarakat untuk menghindari penyimpangan proses birokrasi dan mengikuti prosedur hukum yang berlaku.

\section{DAFTAR PUSTAKA}

Arief, B. N. (2001). Masalah Penegakan Hukum dan Kebijakan Penanggulangan Kejahatan. PT. Citra Aditya Bakti.

H.R., R. (2011). Hukum Administrasi Negara (Edisi Revi). PT Raja Grafindo Persada.

Hamzah, A. (2000). Hukum Acara Pidana Indonesia. Sinar Grafika.

Lamintang, P. A. F. (1991). Delik-Delik Khusus Kejahatan Jabatan dan Kejahatan-Kejahatan Jabatan Tertentu Sebagai Tindakan Pidana Korupsi. Pionir Jaya.

Rahardjo, S. (2010). Masalah Penegakan Hukum suatu Tinjauan Sosiologis. Sinar Baru.

Ramadhani, W. (2017). Penegakan Hukum Dalam Menanggulangi Pungutan Liar Terhadap Pelayanan Publik. Jurnal Hukum Samudra Keadilan, 12(2), 263-276.

Soepardi, E. M. (2009). Memahami Kerugian Keuangan Negara sebagai Salah Satu Unsur Tindak Pidana Korupsi. Ghalia Indonesia.

Sudarto. (1986). Kapita Selekta Hukum Pidana. Alumni.

Wahyudi, K. (1994). Sistem Informasi Manajemen dalam Organisasi Organisasi Publik. Gadjah Mada University Press. 